\title{
Tax Management in Economic Entities of Agricultural Sector
}

\author{
Reshetnyak L.A.* \\ Belgorod State Agricultural University named after \\ V. Gorin \\ Belgorod, Russia \\ e-mail:Lyubov1203@yandex.ru \\ Zolotareva O.I. \\ Belgorod State Agricultural University named after \\ V. Gorin \\ Belgorod, Russia \\ e-mail: savateevaoksana@mail.ru
}

\author{
Demesheva I.A. \\ Belgorod State Agricultural University named after \\ V. Gorin \\ Belgorod, Russia \\ e-mail:demesheva12@mail.ru \\ Zolotarev S.N. \\ Belgorod State Agricultural University named after \\ V. Gorin \\ Belgorod, Russia \\ e-mail: s.n.zolotarev@mail.ru
}

\author{
Bazovkina E.A. \\ Belgorod State Agricultural University named after V. Gorin \\ Belgorod. Russia \\ e-mail: Kostrub-e@mail.ru
}

\begin{abstract}
The subject of the research is taxation systems applied in agricultural organizations. The aim of the research is the choice of tax management tools at the enterprise, which allow reducing the tax burden and increasing organization financial results. The article describes the problem of tax payments optimization in economic entities of the agricultural sector of various organizational and legal forms, types of activities and sizes. As a result of the research the following targets were put and solved: the tax systems of agricultural organizations in the Belgorod region were examined; their content in accordance with the legislation of the Russian Federation; the ratio of GRP and tax payments were analyzed; the share of tax payments used to finance the regional budget has been determined; the share of tax burden on the economy of the region was determined; tax burden for individual agricultural organizations of different directions was calculated. As a result of the calculations the effectiveness of various taxation systems application and the possibility of changing from one system to another one are proved, utilization efficiency of the proposed system and the tax savings were calculated.
\end{abstract}

Keywords - taxes, budget, tax system, tax burden, burden of tax, budget, income.

\section{INTRODUCTION}

As far as we know taxes play a key role in the formation of the state budget revenues, which main burden of payment falls on economic entities. Taxes and fees payment to the budget of the Russian Federation are written in the Article 57 of the Constitution of the Russian Federation: "everyone is obliged to pay legally established taxes and fees" [1].
Therefore, at each stage of development and economic reforms carried out in the country taxation issues are priority for economic entities.

The main tax paid by organizations is income tax, which belongs to federal taxes. For different categories of taxpayers special taxation regimes have been introduced in the Russian Federation:

- Single Agricultural Tax (SAT) - for agricultural enterprises (Article 26.1 Tax Code of the Russian Federation)

- simplified taxation scheme (STS) (Article 26.2 Tax Code of the Russian Federation);

- tax system in the form of a single tax on imputed earnings for certain types of activities (STIE) (Article. 26.3 Tax Code of the Russian Federation)[2].

Economic entities choose independently a taxation system taking into account the features of their activities and according to the requirements of the law. It should be noted that at the same time agricultural sector organizations have privileges in income tax computation. In this case, if the share of revenue from products sale (goods, works and services) is more than $70 \%$ of the total revenue the company is exempted from income tax payment. Therefore, usually agricultural producers use the general taxation system since they are mainly engaged in the production and sale of their own products [8]

Tax system is a complex mechanism requiring competent management. The success of the organization's activity depends on the right approaches to choosing the suitable tax system, which confirms the relevance of the research. 


\section{METHODS AND MATERIALS}

Tax system imperfection encourages organizations to optimize tax payments in order to ensure their own competitiveness. It means that each enterprise based on its capabilities and subject to certain conditions can choose the optimal tax system, which allow them significantly to increase the efficiency of production or trading activities, optimize taxation, and rationally distribute functional responsibilities between structural divisions and contractors.

Choosing one or another system one should take into account the goals and objectives of the organization; make appropriate calculations and determine the application effectiveness of the selected taxation system [3].

The object of the research is economic entities of the agricultural sector of the Belgorod region, which apply various taxation systems: general tax system unified agricultural tax system and the simplified taxation scheme. The subject of the research is the taxation system of agricultural organizations of various organizational forms of ownership and activities.

In the process of the research the selected organizations were grouped by the homogeneity of the applied tax systems; the analysis of their tax burden was carried out. One analyzed the possibilities of using another taxation system in organizations that are different from that one, which actually applied. A comparative analysis of the results was obtained.

In the research abstract-logical, economic-statistical and other research methods were used. The information base for the research was the annual financial statements of economic entities of the agricultural sector, information provided by the Department of Agroindustrial Complex and Environmental Reproduction of the Belgorod Region and by the territorial body of the Federal State Statistics Service in the Belgorod Region, as well as legislative acts and teaching materials.

The research results can be used by agricultural organizations of the Belgorod region when choosing a taxation system, determining the effectiveness of its application to reduce the tax burden and increase the financial result.

\section{RESULTS}

GRP is the most important macroeconomic indicator. In the Belgorod region we form annual $1 \%$ of the total GRP of Russia and $3 \%$ of the GRP of the Central Federal District.

In structure of region's GRP more than $80 \%$ of gross value added is formed in organizations of industrial production, agriculture, trade, construction, transportation and storage.

The growth rate of the main generalizing indicator of the development of the region's economy - the regional GRP since 2006 is higher than the average for Russia and the Central Federal District. At the end of 2017 the index of physical volume of GRP was $103.7 \%$ (4th place in the Central Federal District and 13th in Russia). For 2006-2017 the average annual increase in the physical volume of GRP was 6.6 percent. In the medium term the region's economics will continue to grow at rates exceeding the world level.
GRP is an indicator of assessing the effectiveness of a built-up regional economic policy. The volume and growth rate of GRP are target indicators in developing strategies, programs and shaping the socio-economic policy of the region and they are basis for evaluation of the state and prospects of economic development, building regional economic policies, investment efficiency and labor productivity.

According to the results of 2017 the GRP of the Belgorod region amounted to 785.6 billion rubles in accordance with the Department of Economic Development of the region for 2019 it exceeded 900 billion rubles. By 2021 it is planned to achieve a historical GRP volume of more than 1 trillion rubles.

Belgorod region is among the top leaders in many indicators of socio-economic development. In terms of the volume of GRP produced on average per 1 inhabitant the region takes 3rd place in the Central Federal District after Moscow and the Moscow Region and 18th place among constituent entities of the Russian Federation. It was facilitated by the implementation of the set of measures to increase the GRP approved by Decree of the Government of the region from August 20, 2013 No. 345-pp and defining an action plan to increase the innovative component of regional economics, expand and modernize industrial production, agriculture, construction, trade, increase efficiency the use of foreign economic, natural resource, labor potentials of the region and the functioning of the social sphere.

The regional government put huge efforts in economic and social sphere, constructive cooperation with regional business structures and the population, which made it possible to ensure sustainable economic growth and as a result to raise the wellbeing of the people. Among the regions of the Central Federal District one has observed in the Belgorod Region the lowest level of poverty after Moscow.

In the medium term the regional Government continue the work to achieve strategic development goals defined by Decree of the President of the Russian Federation of May 7, 2018 No. 204 and by the strategy for socio-economic development of the region until 2025, the implementation of regional components of national projects and state programs of the region.

In Belgorod region one can find all taxes and fees that form the tax system of the Russian Federation and the main component of the regional budget [9].

In this case the ratio of the GRP of the region to the tax payments is follow (table 1).

The table shows that the volume of GRP for the analyzed period has increased by $31.2 \%$ and reached 813 billion rubles in 2018 (according to the forecast). Revenues and expenditures of consolidated budget of the region have increased by 46.3 and $33.6 \%$, respectively. Tax revenues into consolidated budget of the region increased by $72.5 \%$. The tax burden on the region economics increased by $2.6 \%$ and reached $10.7 \%$ in 2018 .

In tax planning the evaluation of tax burden and determining its effect on financial results is very significant. 
TABLE I. GROSS PRODUCTION AND TAX PAYMENTS IN BELGOROD REGION FOR 2014-2018*

\begin{tabular}{|l|l|l|l|l|l|l|}
\hline \multicolumn{1}{|c|}{ Indicators } & \multicolumn{5}{|c|}{ Year } & $\begin{array}{l}\text { Growth } \\
\text { rate, \% }\end{array}$ \\
\cline { 2 - 7 } & $\mathbf{2 0 1 4}$ & $\mathbf{2 0 1 5}$ & $\mathbf{2 0 1 6}$ & $\mathbf{2 0 1 7}$ & $\mathbf{2 0 1 8}$ & 131,2 \\
\hline GRP, billion rubles & 619,7 & 693,4 & 729,1 & 785,6 & 813,2 & \\
\hline $\begin{array}{l}\text { Consolidated } \\
\text { budget revenues, } \\
\text { billion rubles }\end{array}$ & 77.6 & 81.1 & 82.1 & 96.8 & 113.5 & 146.3 \\
\hline $\begin{array}{l}\text { Tax payments aimed } \\
\text { at formation of region } \\
\text { budget, billion rubles }\end{array}$ & 50.4 & 56.4 & 57.8 & 72.3 & 86.9 & 172.5 \\
\hline $\begin{array}{l}\text { The share of tax } \\
\text { payments used to } \\
\text { finance the regional } \\
\text { budget, \% }\end{array}$ & 64.9 & 69.5 & 70.4 & 74.7 & 76.5 & - \\
\hline $\begin{array}{l}\text { Budget } \\
\text { expenditures, } \\
\text { billion rubles }\end{array}$ & 79.2 & 83.7 & 85.2 & 95.7 & 105.8 & 133.6 \\
\hline $\begin{array}{l}\text { Deficit (-), surplus } \\
\text { (+) of region } \\
\text { consolidated budget, } \\
\text { million rubles }\end{array}$ & -1619 & -2588 & -3059 & -1142 & 7700 & 475.6 \\
\hline $\begin{array}{l}\text { Tax burden on the } \\
\text { regional economics, } \\
\text { \% }\end{array}$ & 8.1 & 8.2 & 7.9 & 9.2 & 10.7 & - \\
\hline
\end{tabular}

a. * The table is compiled according to the Federal State Statistics Service data in the Belgorod Region

Tax burden indicators of economic entities in the agricultural sector of the Belgorod region are shown in table 2.

TABLE II. LEVEL OF TAXATION OF AGRICULTURAL ORGANIZATIONS OF THE BELGOROD REGION FOR 2014-2018*

\begin{tabular}{|c|c|c|c|c|c|c|}
\hline \multirow{2}{*}{ Indicators } & \multicolumn{5}{|c|}{ Years } & \multirow{2}{*}{\begin{tabular}{|c|} 
Deviation \\
2018г. oт \\
2014r. \\
\end{tabular}} \\
\hline & 2014 & 2015 & 2016 & 2017 & 2018 & \\
\hline $\begin{array}{l}\text { Absolute tax burden } \\
\text { (without personal } \\
\text { income tax), million } \\
\text { rubles }\end{array}$ & 12733 & 13687 & 14909 & 15614 & 20483 & 7750 \\
\hline Revenue, mln. rub. & 214945 & 245548 & 243595 & 247359 & 266260 & 51315 \\
\hline $\begin{array}{l}\text { The average annual } \\
\text { value of assets, } \\
\text { million rubles }\end{array}$ & 245475 & 270352 & 306865 & 342604 & 376977 & 131502 \\
\hline Net profit, mln. rub. & 41817 & 44134 & 34464 & 28329 & 35900 & -5917 \\
\hline \multicolumn{7}{|l|}{ Tax burden, $\%$} \\
\hline - on revenue & 5.92 & 5.57 & 6.12 & 6.31 & 7.69 & 1.77 \\
\hline - on assets & 5.19 & 5.06 & 4.86 & 4.56 & 5.43 & 0.24 \\
\hline - on net profit & 30.45 & 31.01 & 43.26 & 55.12 & 57.05 & 26.60 \\
\hline
\end{tabular}

b. * The table is compiled according to the Department of Agroindustrial Complex and Environmental Reproduction data.

It is seen from the data in the table that for 2014-2018 the amount of tax charged and insurance contributions in agricultural organizations of the region increased by 7750 million rubles or $60.9 \%$. Revenue has increased by 51315 million rubles or $24.9 \%$, the average annual value of assets increased by 131502 million rubles or $53.58 \%$. Net profit, on the contrary, has decreased by 5917 million rubles or $14.1 \%$. Due to significant increasing in tax payments an increase in tax burden on agricultural producers is observed. So, with an eye to revenue, it has increased by $1.77 \%$ and amounted to $7.69 \%$, on assets by $5.43 \%$, which is higher than figures in 2014 by $0.24 \%$. As for the net profit, the tax burden has increased almost twice: from 30.45 to $57.05 \%$.

As it was previously noted for agricultural enterprises tax legislation provides for both general taxation regime and special regimes, which distinguishes agricultural production from other activities. Agricultural enterprises can apply various tax benefits established by the Tax Code of the Russian Federation.

Under the general taxation regime for agricultural producers one provides a zero tax rate on income for activities related to the sale of agricultural products distribution as well as their primary processing. In the selling other products as well as work performance and providing services or sale of property, income tax should be calculated at a rate of $20 \%$.

As for property tax federal tax law does not provide any benefits. They can be introduced by regional legislation representative bodies of territorial entity of the RF. Therefore, tax benefits for this tax depend on the regions [4].

The preferences were introduced by the Tax Code of the Russian Federation according to transport tax. Agricultural producers do not calculate tax on certain types of equipment used during the agricultural work for agricultural production.

According to land tax the Tax Code of the Russian Federation provides a reduced rate for agricultural land - not more than $0.3 \%$ and for non-agricultural land - not more than $1.5 \%$. This is very important for agricultural production as land is the main means of production for farmers. The final land tax rate is set by municipalities.

Agricultural producers can also apply special taxation regimes - Single Agricultural Tax, the simplified tax system, the UTII.

For enterprises of agroindustrial complex it is established a voluntary procedure for the transition to Single Agricultural Tax. The main requirement is $70 \%$ or more of revenue from the agricultural products sale and their primary processing products from the total revenue. The Single Agricultural Tax replaces income tax (except for tax on dividends and certain types of debt obligations), property tax (except for property at cadastral value) and until 2019 value added tax (excluding import) [7].

Thus, under Single Agricultural Tax payment: it is reduced the number of paid taxes and tax pressure on small and unprofitable farms; most enterprises can pay tax once (at the end of the tax period) since the first half of the calendar year in most cases is the most costly one; bookkeeping is simplified; tax rate is $6 \%$.

The simplified taxation system is regulated by Chapter 26.2 of the Tax Code of the Russian Federation. In order to come over the simplified taxation system the taxpayer must meet the established criteria. In addition, taxpayers should choose the object of taxation. There are two options: income, 6 $\%$ tax rate; income reduced by the amount of tax rate of $15 \%$. It is possible to differentiate the tax rate by constituent entities of the Russian Federation from 5 to $15 \%$, which is written in the Tax Code. In the Belgorod Region for agricultural 
organizations under the second option for the object of taxation the tax rate is $5 \%$.

Agricultural enterprises of the Belgorod region are in various taxation regimes. According to the Department of Agroindustrial Complex and Environmental Reproduction of the Belgorod Region only $35.7 \%$ of agricultural enterprises use taxation system for agricultural producers and $5.7 \%$ use simplified taxation system from 210 enterprises in 2018.
In 2018 tax burden on revenue for organizations that are under the standard taxation scheme was $7.9 \%$, for enterprises with Single Agricultural Tax it was $3.6 \%$, for organizations with simplified tax system it was $10.5 \%$. Thus, the majority of organizations have lower tax burden rather than one for individuals $(13 \%)$

The level range of tax burden under various taxation regimes is different (table 4 ).

TABLE III. TAX BURDEN OF AGRICULTURAL ORGANIZATIONS IN THE BELGOROD REGION USING VARIOUS TAXATION REGIMES FOR 2018

\begin{tabular}{|c|c|c|c|c|c|c|c|}
\hline \multirow{2}{*}{$\begin{array}{l}\text { Group of organizations on } \\
\text { the used tax regime }\end{array}$} & \multicolumn{2}{|c|}{ Number of organizations } & \multicolumn{2}{|c|}{$\begin{array}{c}\text { Revenue } \\
\text { (without VAT) }\end{array}$} & \multicolumn{2}{|c|}{$\begin{array}{l}\text { Amount of tax, fees and insurance } \\
\text { premiums(without personal income tax) }\end{array}$} & \multirow{2}{*}{$\begin{array}{c}\text { The tax } \\
\text { burden, } \\
\%\end{array}$} \\
\hline & units & $\%$ to total & million rubles & $\%$ to total & million rubles. & $\%$ to total & \\
\hline $\begin{array}{l}\text { Organizations with } \\
\text { standard taxation scheme }\end{array}$ & 123 & 58.6 & 256668 & 96.4 & 20118 & 98.2 & 7.9 \\
\hline $\begin{array}{l}\text { Organizations with unified } \\
\text { agricultural tax }\end{array}$ & 75 & 35.7 & 9296 & 3.5 & 333 & 1.6 & 3.6 \\
\hline $\begin{array}{l}\text { Organizations with } \\
\text { simplified tax system }\end{array}$ & 12 & 5.7 & 296 & 0.1 & 31 & 0.2 & 10.5 \\
\hline $\begin{array}{l}\text { All agricultural } \\
\text { organizations }\end{array}$ & 210 & 100 & 266260 & 100 & 20482 & 100 & 7.7 \\
\hline
\end{tabular}

c. * The table is compiled according of the Department of Agroindustrial Complex and Environmental Reproduction data.

TABLE IV. RANKING OF THE TAX BURDEN OF INDIVIDUAL ECONOMIC ENTITIES OF THE BELGOROD REGION FOR 2018 *

\begin{tabular}{|c|c|c|c|c|c|c|}
\hline \multirow{4}{*}{ Indicators } & \multirow{2}{*}{\multicolumn{2}{|c|}{ General tax system }} & \multicolumn{4}{|c|}{ Special tax regimes } \\
\hline & & & \multicolumn{2}{|c|}{ Single Agricultural Tax } & \multicolumn{2}{|c|}{ Simplified system of taxation } \\
\hline & $\begin{array}{c}\text { Low level of tax } \\
\text { burden }\end{array}$ & $\begin{array}{l}\text { High level of tax } \\
\text { burden }\end{array}$ & $\begin{array}{c}\text { Low level of tax } \\
\text { burden }\end{array}$ & $\begin{array}{l}\text { High level of } \\
\text { tax burden }\end{array}$ & $\begin{array}{c}\text { Low level of tax } \\
\text { burden }\end{array}$ & High level of tax burden \\
\hline & $\begin{array}{l}\text { Ltd. "Agroinvest- } \\
\text { Timonovo" } \\
\text { Valuisky region } \\
\end{array}$ & $\begin{array}{c}\text { Ltd. "Belgrankorm } \\
\text { Holding" } \\
\text { Rakityansky District }\end{array}$ & $\begin{array}{l}\text { Ltd. "Kolos" } \\
\text { Grayvoronsky } \\
\text { district } \\
\end{array}$ & $\begin{array}{c}\text { Ltd "Bionica" } \\
\text { Alekseevsky } \\
\text { district } \\
\end{array}$ & $\begin{array}{c}\text { Ltd. "Rassvet" } \\
\text { Rakityansky } \\
\text { district }\end{array}$ & $\begin{array}{c}\text { 3АО «Рыбхоз limited } \\
\text { company "Borisovsky" } \\
\text { Borisovsky district paйона }\end{array}$ \\
\hline Revenues, thousand rubles & 199588 & 431822 & 5643 & 8124 & 9937 & 8540 \\
\hline $\begin{array}{l}\text { Profit fon a sale, thousand } \\
\text { rubles }\end{array}$ & 12381 & 32246 & 313 & 2194 & 2368 & 413 \\
\hline \multicolumn{7}{|l|}{ On revenue, $\%$} \\
\hline $\begin{array}{l}\text { - creditor indebtedness to } \\
\text { the budget and non- } \\
\text { budgetary funds at the end } \\
\text { of the year }\end{array}$ & 0.12 & 4.6 & 0.37 & 1.32 & - & 1.17 \\
\hline - tax payments charged & 1.36 & 37.88 & 1.36 & 32.5 & 2.26 & 18.51 \\
\hline - tax payments paid & 1.35 & 37.22 & 1.40 & 31.6 & 2.26 & 19.67 \\
\hline
\end{tabular}

Ltd. "Agroinvest-Timonovo" in the Valuisky district applies a general taxation system and pays five types of tax payments and insurance premiums. The effective business implementation leads to a low tax burden on the company's revenue - only $1.36 \%$. At the same time in Ltd. "Belgrankorm-Holding" in Rakityansky district this indicator is $37.88 \%$. The annual sales volume in these enterprises is 199588 thousand rubles and 431,822 thousand rubles respectively, the sale financial result is 12381 thousand rubles and 32246 thousand rubles of benefit.

Similar situation is observed in farms, which apply a special tax regime for rural producers. Ltd. "Kolos" in the Grayvoronsky district pays tax and insurance payments in accordance with the Single Agricultural Tax legislation and with the annual sales volume of 5643 thousand rubles has a tax burden $1.36 \%$. At the Ltd. "Bionika" in the Alekseevsky district these indicators are 8124 thousand rubles and $32.5 \%$ respectively.
For agricultural producers with simplified system of taxation the tax burden fluctuations are less. The lowest tax burden is observed in Ltd. "Rassvet", Rakityansky district: $2.26 \%$ with an annual sales volume of 9937 thousand rubles and sales profit of 2368 thousand rubles. The highest tax burden in CJSC "Rybkhoz Borisovsky" in the Borisovsky district is $18.51 \%$. At the same time the organization's sales revenue was 8540 thousand rubles in 2018 and sales profit is 413 thousand rubles.

The analysis of the national scientists and economists publications has found out the following negative aspects of Single Agricultural Tax application:

- constant calculation of share of proceeds from sales of agricultural products in the total revenue of the enterprise (it should be more than $70 \%$ ) [11];

- The bloated price of acquired fixed assets, intangible assets, raw materials and materials necessary for 
production. VAT payers provide such material resources. VAT paid by suppliers applying the Single Agricultural Tax is to be charged to the organization expenses. This leads to a significant increase in the cost of agricultural products and decrease its competitiveness and decline of the taxpayer financial results $[10]$

- the reluctance of processing enterprises to work with agricultural producers with Single Agricultural Tax. For processing enterprises in most cases under standard taxation scheme it is more profitable from an economic point of view to purchase raw materials from organizations - VAT payers. As for enterprises, which use Single Agricultural Tax, they in fact should reduce the products price when disposal of goods by the amount of VAT. But in practice, this does not happen as everyone strives to sell products more expensive. As for VAT the rate of $10 \%$ is used for the sale of bought agricultural products, materials, goods, work and services as well as leasing payments and they are subject to tax at the basic rate, which is $20 \%$ today. As the result the amount of VAT paid to suppliers and contractors is sometimes higher than that one, which is charged at the sale of agricultural products. In this case organizations have a right to refund VAT. Hence the taxation burden is reduced for economic entities with general tax system and products competitiveness increase;

- a closed list of expenses for the tax base formation is established by the Tax Code of the Russian Federation on the Single Agricultural Tax. It is annually upward, but this is not enough. In accordance with the general tax regime organizations have the right to reduce the tax base for tax on income for all types of expenses if they comply with the conditions of tax legislation;

- the need for accounting on an accrual basis for the preparation of financial statements and cash method for computation of unified agricultural tax. Cash method computation is carried out with significant violations of tax legislation, with deviations in income and expenses according to the Federal Tax Service data in $10 \%$ of cases.

The transition to a simplified tax system allows paying a single tax at a reduced rate, which exempts organizationstaxpayers from VAT (excluding import), income tax, property tax (excluding property, tax base for which is calculated at the cadastral value). The next advantage of simplified tax system is a simplified procedure for accounting and reporting. Registration for taxation in such organizations is maintained in income and expenditure ledger. The tax return is to be submitted once - until March 31 of the next year.

The disadvantages of the simplified tax system include:

- difficulty in finding counterparties. Organizations with the simplified tax system do not include VAT in the cost of products, goods and services. Counterpartiesbuyers with general taxation system can not accept deductible tax and for them it is unprofitable;
- we have to monitor constantly the criteria for the possibility of using special modes.

Therefore, when a decision is made by agricultural producers on the transition to general or special taxation regime calculations should be made in relation to specific operating conditions. In this case one should to take into account increasing of financial results rather than decreasing of the amount of tax payments. It is profit that predetermines the entrepreneurial point of agricultural production development.

Let's consider the profitability of Single Agricultural Tax application for Kirov collective farm in the Veidelevsky district. The main organization activity is crops cultivation. The collective farm has special tax regime in the form of Single Agricultural Tax. Let's compare the effectiveness of application of Single Agricultural Tax and the general taxation system for this enterprise (table 5).

TABLE V. TAX EFFECTIVENESS OF KIROV COLLECTIVE FARM IN THE VEIDELEVSKY DISTRICT UNDER THE GENERAL TAXATION REGIME AND SINGLE AGRICULTURAL TAX

\begin{tabular}{|l|l|l|}
\hline \multirow{2}{*}{ Indicators } & \multicolumn{2}{c|}{$\begin{array}{c}\text { Tax charged amount, thousand } \\
\text { rubles }\end{array}$} \\
\cline { 2 - 3 } & $\begin{array}{c}\text { Upon payment } \\
\text { of Single } \\
\text { Agricultural Tax } \\
\text { (fact 2018) }\end{array}$ & $\begin{array}{c}\text { Under the } \\
\text { general taxation } \\
\text { system (forecast) }\end{array}$ \\
\hline Tax charged including: & 3172 & 3744 \\
\hline -tax on profits & - & 169 \\
\hline - value Added Tax & - & -960 \\
\hline - corporate property tax & 144 & 1630 \\
\hline - water tax & 72 & 72 \\
\hline - land tax & 2528 & 2528 \\
\hline - transportation tax & 298 & 298 \\
\hline - Single Agricultural Tax & 123 & - \\
\hline - other taxes & 7 & 7 \\
\hline insurance fees & 11342 & 11342 \\
\hline $\begin{array}{l}\text { Total amount of taxes and } \\
\text { insurance fee }\end{array}$ & 14514 & 15086 \\
\hline Revenue & 139537 & 139537 \\
\hline Tax burden, \% & 10.40 & 10.81 \\
\hline $\begin{array}{l}\text { Tax saving (+), Losses (-) } \\
\text { with the transition to general } \\
\text { taxation system: }\end{array}$ & - & 14782 \\
\hline including due to: & & -572 \\
\hline - changes of tax payments & - & 10850 \\
\hline - decreasing of product cost & - & 4504 \\
\hline - deduction on fixed assets & - & 15972 \\
\hline Net profit & 1190 & \\
\hline & & -19 \\
\hline
\end{tabular}

e. $*$ The table is compiled according to the accounting (financial) statements of the Kirov collective farm of the Veidelevsky district for 2018

From the calculations it is clear that when organization uses general tax system tax payments increase from 14514 thousand rubles up to 15086 thousand rubles and accordingly the tax burden increases from 10.40 to $10.81 \%$. Although the application of the general taxation system increases the tax burden on the enterprise, however, this regime is beneficial for the enterprise since the amount of net profit increases from 1190 thousand rubles up to 15972 thousand rubles. This is linked with a reduction of agricultural products cost by 10,850 thousand rubles due to a possible VAT charge as well 
as a cost decrease of acquired fixed assets by 4504 thousand rubles. Therefore, it can be argued that the special regime application in the form of Single Agricultural Tax in 2018 for the collective farm named after Kirov in the Veidelevsky district is not economically advantageous. General taxation system could allow the company to increase its own financing sources and improve its financial condition.

Since 2019 the norm of article 346.1 (3) of the Tax Code of the Russian Federation has ceased to have effect, according to which payers of the Single Agricultural Tax have been exempted from VAT (except for import) [5]. It means that on a Single Agricultural Tax one should to:

- charge VAT upon sale of goods, works, services and upon receipt of advances;

- transfer to the customers invoices with the allocated amount of VAT within five days;

- request invoices from suppliers to account of input VAT;

- have the necessary prudence and caution when choosing a counterparty (as not to get rejection of relief);

- $\quad$ keep sales and purchases ledger;

- submit a VAT return in electronic form every quarter;

- transfer VAT to the budget in time (three equal parts and no later than the 25 th day of each of the three months following the reporting quarter).

TABLE VI. EFFECTIVENESS OF THE Single Agricultural TAX APPLICATION IN LTD. "POLESIE" IN THE BORISOVSKY DISTRICT

\begin{tabular}{|l|l|l|}
\hline \multirow{2}{*}{ Indicators } & \multicolumn{2}{c|}{ Tax charged amount, thousand rubles } \\
\cline { 2 - 3 } & \multicolumn{1}{|c|}{$\begin{array}{c}\text { when VAT tax } \\
\text { exemption }\end{array}$} & $\begin{array}{c}\text { When paying VAT } \\
\text { (forecast) }\end{array}$ \\
\hline Tax charged including: & 164 & 1111 \\
\hline - land tax & 35 & 35 \\
\hline - unified agricultural tax & 125 & 125 \\
\hline - VAT & - & 944 \\
\hline - other taxes & 4 & 7 \\
\hline Insurance fees & 1086 & 1086 \\
\hline $\begin{array}{l}\text { Total amount of taxes and } \\
\text { insurance fee }\end{array}$ & 1250 & 2197 \\
\hline Revenue & 17614 & 17614 \\
\hline Tax burden. \% & 7.10 & 12.47 \\
\hline Tax saving (+). Losses (-) & & -127 \\
\hline including due to: & & -944 \\
\hline - changes in tax payments & - & 817 \\
\hline - reduce production costs & - & 1951 \\
\hline Net profit & 2085 & \\
\hline
\end{tabular}

f. * The table is compiled according to the accounting (financial) statements of Ltd "Polesie" in the Borisovsky district for 2018

Being a VAT payer without refusing at the same time from special regime according to the Single Agricultural Tax is beneficial primarily to large enterprises, which purchase expensive machinery and equipment. Small business entities may be exempted from this obligation. The exemption is provided if the taxpayer income does not exceed 100 million rubles in 2018, 90 million rubles in 2019, 80 million rubles in 2020.
Let us evaluate the profitability of VAT paying for Ltd. "Polesie" in the Borisovsky district, a micro-enterprise engaged in the cultivation of grain crops (table 6).

According to the calculation results it was found that paying VAT is not profitable for the company. This may adversely affect at the organization net profit. Therefore, Ltd "Polesie" should use the right to exemption from VAT.

\section{CONCLUSION}

Minimizing tax payments without law violating is the main target of the organization- taxpayer. Taxes instability, constant rates review, the amount of taxes, benefits, etc. have a negative role in the financial activities of the organization.

Current legislation strictly regulates the types of taxes paid by the enterprise, rates, the procedure of tax base formation, which directly depends on the amount of paid taxes and other issues. At the same time there are various options of tax systems, the choice of which is independently carried out by the organization.

The calculations have found that for individual enterprises with Single Agricultural Tax it is advantageous to use general tax system. For example, such system does not allow the Kirov collective farm to do savings on taxes, but it significantly increases net profit.

As for another economic entity Ltd. "Polesie" it is profitable to use the Single Agricultural Tax with the exemption from VAT, which will both reduce the tax burden and increase profits.

If it is not possible to reduce simultaneously the tax burden and increase financial result at the same time then in this case priorities should be determined, which is more important for the organization and then the results will be quite expected.

\section{References}

[1] Constitution of the Russian Federation. Retrieved from: http://www.constitution.ru/

[2] Tax Code of the Russian Federation: part 1-2. Retrieved from: https://legalacts.ru/kodeks/NK-RF-chast-2

[3] V.Y. Padalkin., G.N. Strukov, A.M. Prygunkov, L.I. Churikov, "The impact of tax planning on the level of economic security of the company", Proc. of the Voronezh State Univer. of Engineer. Technol., vol. 81, no. 2, pp. 383-386, 2019. Retrieved from: https://doi.org/10.20914/2310-1202-2019-2-383-386

[4] A.I. Khorev, G.V. Belyaeva, A.N. Polozova, R.V. Nuzhdin, "The optimization procedure in the tax system, the processing organizations", Proc. of the Voronezh State Univer. of Engineer. Technol., vol. 81, no. 1, pp. 357-365, 2019. Retrieved from: https://doi.org/10.20914/2310-1202-2019-1-357-365

[5] O.I. Zolotareva. "Tax Planning at an Agricultural Enterprise", pp. 209-210, May 2019, Innovative Solutions in Agricultural Science - A Look into the Future [Mater. of the XXIII Int. sci.-industr. Conf., 324 p., 2019].

[6] I.A. Demesheva, E.V. Tetyurkina, Evaluation of the tax burden of agricultural organizations in the region, Monograph. 2017, $92 \mathrm{p}$.

[7] L.A. Reshetnyak, "Advantages and disadvantages of the Single Agricultural Tax for Agricultural Producers", Innovat. in the agroindustrial complex: probl. and prosp., vol. 3, no. 23, pp. 99-105, 2019.

[8] V.R. Volobuev, J.I. Zdorovets, "New in accounting and tax registration", p. 92, February 2016 [Mater. of the Int. Student Sci. Conf., 412 p., 2016]. 
[9] E.A. Golovaneva, "Choice of a method for calculating depreciation in order to optimize taxation on the example of Belgorod Dairy Farms", Sci. Diary, vol. 10, no. 10, p. 25, 2017.

[10] O.I. Bundina, A. Panin, J.A. Bozhchenko, "Stimulating the interest of participants in agricultural enterprises to maximize profits", Ration. and remunerate. in agricult., no. 4, pp. 30-40, 2015.
[11] A.N. Prostenko, V.L. Anichin, A.I. Khudobin, "Tax incentives as a tool to stimulate investment activity in the region", Bull. of the Kursk State Agricult. Acad., no. 2, pp. 162-166, 2019. 